\title{
Determining the Key Factors for the Advertisement on Micro Cinema Using Grey Relational Analysis and Dramaturgy Model
}

\author{
Jia-Fen $\mathrm{Wu}$ \\ National Chung Hsing University, Taiwan \\ aliceabcd37@gmail.com \\ Tzong-Ru Lee \\ National Chung Hsing University, Taiwan \\ trlee@dragon.nchu.edu.tw \\ Irsan Prawira Julius Jioe \\ National Chung Hsing University, Taiwan \\ sack2pj@yahoo.com \\ Chun-Yu Chien \\ Asia University in Taiwan \\ chien_ivy@hotmail.com \\ Lesse L. Mendy \\ National Chung Hsing University, Taiwan \\ leesemendez@yahoo.co.uk
}

\begin{abstract}
Technology advancement has seemingly made the world smaller, especially with the existence of tools such as a cell phone. Along with this development, new method of marketing and promotion has been formed. One of these strategies is the use of micro cinema. After sufficient background study on the factors that seemed to affect the effectiveness of micro cinema, these factors were then used to study the response by Taiwanese students and a working group as well as the working group from Mainland China. Responses obtained from all groups were then analyzed using grey relational analysis (GRA) and then further analyzed using the modified dramaturgy model by Grove et al. (1992). The result obtained can be used to represent the important factors in micro cinema affecting each group.
\end{abstract}

Keywords - micro cinema, micro cinema advertisement, grey relational analysis, dramaturgy model, technology, Mainland China, Taiwanese students
Determining the Key

Factors for the Advertisement on Micro Cinema Using Grey Relational Analysis and Dramaturgy Model 
IJSR 7

\section{Introduction}

The development of new media has brought changes in customer habits, and the method of marketing has also shifted from simple selling products to gaining the spiritual level (Hu, 2014). Radstone (2010) stated that "the theories of cinema's relation to memory have hinged on meta-psychological accounts of the cinema". The scene of self-staging is meaningful to others. The micro-movie story marketing came into at the time to use the innovation of the communication channel and the "differentiation of emotions" $(\mathrm{Hu}$, 2014), and it provides a new channel for the marketing (Kuo, 2016). Asian market put in more and more effort in using micro cinema as a platform to advertise and create awareness to new merchandises in recent years. Micro film has been the main form of various video competitions; production of advertising film has become a trend (Ho, 2013). Communication channels such as portal websites, social media, traditional television, and variety of military Internet websites can be used for micro film (Hu and Chen, 2013). The factor that determines the success of micro cinema was unknown. With the increase of the number of smart phones, tablets and other mobile devices, the level of information flow becomes higher. The concept of micro cinema was formed that we use a form of a short video to tell a story, an idea or even a promotion for a new product. In addition, micro-movie has played different roles in the different stages of brand communication (Wu, 2017; Shen, 2013).

In order to find out the important factors influencing the success of micro cinema, this study has reviewed related literature, designed questionnaires, used grey relational analysis (GRA) as well as dramaturgy model to find and sort the important elements in a micro cinema advertisement.

\section{Micro cinema}

Micro cinema can cover anything - micro movies with low-budget or amateur films shot mostly on digital video, edited on a computer, and then distributed via videotape, disc or over the Internet (Wikipedia, 2017). In recent years, various types of minicinema advertisement were produced. This study focuses mainly on its function as advertisement.

\subsection{Factors in micro cinema advertisement}

As mobile devices and the Internet become more common along with the increase in network speed, e-marketing also continues to change. Combination of micro cinema with advertisement became one of the most popular marketing methods in Mainland China. Compared to past Internet marketing method which used such methods as virus marketing and spyware, micro cinema advertisement received a much better acceptance. This study was meant to find the main factors which greatly attracted users to the micro cinema. According to the literature, many factors can affect micro cinema advertisement and these factors as well as their sources are provided in Table 1. 
Pobrane z czasopisma International Journal of Synergy and Research http://ijsr.journals.umcs.pl

Data: 26/04/2023 13:20:57

\begin{tabular}{|c|c|c|}
\hline Authors & Code & References related to micro cinema \\
\hline \multirow[b]{2}{*}{ Liu and Tsai (2012) } & 1 & Create a bond with consumers by using emotional theme to capture their interest \\
\hline & 2 & $\begin{array}{l}\text { Avoid being too commercialized and create contents that will attract users and make them } \\
\text { willing to share it to others }\end{array}$ \\
\hline \multirow{4}{*}{ Zhang (2012) } & 3 & Utilized good story to appeal to the audience \\
\hline & 4 & Rich creative elements \\
\hline & 5 & Creative expression \\
\hline & 6 & Combine with activity to increase exposure \\
\hline \multirow{3}{*}{ Chen (2012) } & 7 & Use idols to perform \\
\hline & 8 & Greatly increase advertising budget on TV and Internet to increase exposure \\
\hline & 9 & Present brand/product in the most natural manner \\
\hline Liou (2012) & 10 & Combine public film with business \\
\hline \multirow[b]{2}{*}{ Lee (2012) } & 11 & At the start of the movie, present a suspense which will attract the audience's curiosity \\
\hline & 12 & $\begin{array}{l}\text { Music is one of the most important factors since music can stimulate emotions which can be } \\
\text { used to establish an appropriate mood in the movie }\end{array}$ \\
\hline Kang (2012) & 13 & Micro-film should grasp focus and customization \\
\hline Pai and Lu (2012) & 14 & $\begin{array}{l}\text { The presentation of the product by the story must show the role of the product in the story. It } \\
\text { can be in a form of simple tool to various key factors of the environment within the story. It is } \\
\text { only then that the existence of the product can enter the mind of the audience. }\end{array}$ \\
\hline Zhu (2011) & 15 & Humor can be used to attract the public \\
\hline \multirow{6}{*}{ Liou (2013) } & 16 & Suitable length so that it can be watched anytime \\
\hline & 17 & The movie has to be well made \\
\hline & 18 & Attractive content is necessary \\
\hline & 19 & Guidance of famous director \\
\hline & 20 & Presence of famous actor \\
\hline & 21 & Overly obvious commercial will cause rejection from the audience \\
\hline $\operatorname{Lin}(2013)$ & 22 & Micro cinema needs to have a sufficient level of commercial value in order to attract customers \\
\hline \multirow{2}{*}{ Chen (2013) } & 23 & Good story is an important factor \\
\hline & 24 & Good understanding of the taste of users \\
\hline \multirow{2}{*}{ Qu (2013) } & 25 & Great creativity can have great prospects \\
\hline & 26 & Interesting micro cinema can have great prospects \\
\hline Chen (2013) & 27 & $\begin{array}{l}\text { Micro cinema that can attract people has sufficient amount of emotional value which the } \\
\text { people can relate to }\end{array}$ \\
\hline $\begin{array}{l}\text { Erdogan et al. } \\
(2001)\end{array}$ & 28 & Famous representatives usually have higher rating \\
\hline $\begin{array}{l}\text { Orth and } \\
\text { Oppenheim (2005) }\end{array}$ & 29 & Advertisement needs to be suitable to the cultural background of the community \\
\hline Cline et al. (2003) & 30 & From past experiences and data, an advertisement with humor will have higher rating \\
\hline \multirow[b]{2}{*}{ Baldwin (1997) } & 31 & Advertisement content use words and music as support to achieve resonance \\
\hline & 32 & $\begin{array}{l}\text { Lyrics can improve the emotional aspect of the micro cinema advertisement as well as the } \\
\text { characteristics of the product }\end{array}$ \\
\hline $\begin{array}{l}\text { Cline and Kellaris } \\
(2007)\end{array}$ & 33 & $\begin{array}{l}\text { General usage of humorous advertisement proves that advertisement which are funny increase } \\
\text { the effectiveness of the advertisement }\end{array}$ \\
\hline Bayles (2002) & 34 & $\begin{array}{l}\text { Products inserted into games can bring about trust in terms of the efficiency of the product to } \\
\text { gamers. However, if it is done improperly, it will bring about the opposite effect }\end{array}$ \\
\hline
\end{tabular}

Determining the Key

Factors for the Advertisement on Micro Cinema Using Grey Relational Analysis and Dramaturgy Model

Table 1.

References related to micro cinema advertisement 


\section{IJSR \\ 7}

Table 1.

References related

to micro cinema

advertisement

\begin{tabular}{ccl}
\hline \multicolumn{1}{c}{ Authors } & Code & \multicolumn{1}{c}{ References related to micro cinema } \\
\hline McCarty (2004) & 35 & $\begin{array}{l}\text { If the product presentation is overly obvious within the movie, it may bring about aversion to } \\
\text { the product from the audience }\end{array}$ \\
\hline Liao et al. (2014) & $\begin{array}{l}\text { For luxury goods, an advertisement through micro cinema needs to be able to create an } \\
\text { atmosphere and brand it }\end{array}$ \\
\cline { 2 - 3 } & $\begin{array}{l}\text { Micro cinema which mainly utilize its story, inserted the brand or information of the product } \\
\text { into the movie. This method allows the audience to accept the information as a form of } \\
\text { experience which will allow the audience to unconsciously add some value towards the product } \\
\text { and allow the product to resonate with the audience }\end{array}$ \\
\hline
\end{tabular}

Source: Authors' own study.

\section{Grey relational analysis (GRA)}

Grey system theory is a theory proposed by Professor Julong Deng in 1982. It is a method to analyze the relationship degree between factors. This theory mainly acts upon the unpredictable variables and variables whose information is insufficient within the system. These variables are then analyzed in accordance with its relative importance and designed into a relatedness analysis model (Huang and Liao, 2012).

Under the theoretical framework of grey system, the method of grey relational analysis (GRA) was proposed to measure the correlation factors in the similarities and dissimilarities among the various factors. This method requires low samples (as low as 4 samples) and does not require typical distribution and does not have to be similar to regression analysis which requires suitable distribution and assumptions (Zhang, 2011). Therefore, grey relational theory is used to analyze the results of the questionnaire. Grey correlation analysis calculation formula comprises of six steps:

(1) Identify reference sequence compared with the number of columns: From the original matrix D find the reference sequence A0 and compare it with sequence A1, reference sequence numbers are the factors selected from the questionnaires. Comparison of each factor to obtain their performance value.

(2) Standardization of value: the original data from matrix D was used to find the standardization (the higher the value the better).

$$
x_{i j}^{*}=\frac{x_{i j}-\min _{i} x_{i j}}{\max _{i} x_{i j}-\min _{i} x_{i j}}
$$

In which, $\max _{i} X_{i j}$ is the highest value in $j ; \min _{i} X_{i j}$ is the lowest value in $j$.

(3) Calculate the correlation value of $\Delta_{o i j}: \Delta_{o i j}$ was used to measure the distance between a normalized value and reference value of normalized data.

$\Delta_{o i j}=\left|x_{o j}^{*}-x_{i j}^{*}\right|$

(4) Calculate grey relationship coefficient, $\gamma_{\sigma i j}$

$\gamma_{o i j}=\frac{\Delta \min +\mathfrak{I} \Delta \max }{\Delta_{\sigma i j}+\mathfrak{I} \Delta \max }$ 
In which, $\Delta \max =\max _{i} \max _{i} \Delta_{\sigma i j}, \Delta \min =\min _{i} \min _{i} \Delta_{o i j}, \mathfrak{J} \in[0,1] . \mathfrak{J}$ is the identification value for the purpose of controlling the size of grey correlation coefficient. Generally, 0.5 is the benchmark (Deng, 1989) thus, this study used 0.5 as the identification factor.

(5) Grey relational grade $\left(\Gamma_{\sigma i}\right)$ : Each grey correlation coefficient is the mean of grey correlation degree; these values were considered as the gray correlation degree of factors. The higher the value, the more important the factor.

$$
\Gamma_{\sigma i}=\sum_{j=1}^{n} \gamma_{\sigma i j}
$$

(6) Gray relation sequence: Important factors were selected according to the gray correlation degree and decided in accordance with the comparison on the calculated value of gray relational degree $\Gamma_{\sigma i}$, when $\Gamma_{\sigma i}$ value is big, the more important the factor.

GRA has wide usage (Hsu et al., 2015; Chen et al., 2014, Chiu et al., 2014, Lee et al., 2012, Chen et al., 2010) and scholars of various levels used GRA in the social research. Thus, this study used GRA to extract the important factors influencing micro cinema advertisement.

\section{Dramaturgy model}

According to Goffman (1959), the main idea on the theory was first found when researching on social interaction. As for the study on inter human relationship, the dramaturgy model was proposed. In this model, the fact that certain behavior is regarded as important is due to the evolution of the people who placed importance in the behavior. The performance also included other people's effort when impressing other people. Social behavior is social performance. In the stage called society, members of society will perform their roles carefully and they will leave a desirable image of themselves (Chen 2002).

Grove et al. (1992) developed the structure of dramaturgy model. When entering a performance, the performance was formed out of four main factors:

1. Actor: Performers who play the roles in the micro cinema advertisement.

2. Audience: Users, people who watched micro cinema.

3. Location: Location where the micro cinema advertisement was performed or recorded. 4. Performance: Process of performing the actions which will include the interaction between actors and the audience.

\section{Research method}

\subsection{Summary of factors affecting micro cinema advertisement and its development into questionnaire}

Table 2 was formed on the basis of Table 1 which was derived from various literature. Summary of factors affecting micro cinema advertisement was sorted in accordance with the development of its questionnaire. By following the original code in Table 2, we find the corresponding literature in Table 1.
Determining the Key

Factors for the Advertisement on Micro Cinema Using Grey Relational Analysis and Dramaturgy

Model 
Pobrane z czasopisma International Journal of Synergy and Research http://ijsr.journals.umcs.pl

Data: 26/04/2023 13:20:57

38

IJSR

7

\begin{tabular}{|c|c|c|c|}
\hline $\begin{array}{l}\text { Original } \\
\text { code }\end{array}$ & $\begin{array}{l}\text { Factors affecting } \\
\text { micro cinema } \\
\text { advertisement }\end{array}$ & $\begin{array}{l}\text { New } \\
\text { code }\end{array}$ & Questionnaire options \\
\hline 1 & \multirow{3}{*}{ Focus on emotion } & \multirow{3}{*}{$(1)$} & \multirow{3}{*}{$\begin{array}{l}\text { Whether or not the micro cinema advertisement focuses on emotion it is an } \\
\text { important factor in attracting users }\end{array}$} \\
\hline 27 & & & \\
\hline 37 & & & \\
\hline 2 & \multirow{3}{*}{$\begin{array}{l}\text { - Level of } \\
\text { - commercialization }\end{array}$} & \multirow{3}{*}{ (2) } & \multirow{3}{*}{$\begin{array}{l}\text { Whether the level of commercialization is one of the factors which affect the } \\
\text { number of users }\end{array}$} \\
\hline 21 & & & \\
\hline 22 & & & \\
\hline 34 & \multirow{2}{*}{ - Subtlety } & \multirow{2}{*}{ (3) } & \multirow{2}{*}{$\begin{array}{l}\text { Whether the subtlety of the placement of product in the movie can affect the } \\
\text { number of viewers }\end{array}$} \\
\hline 35 & & & \\
\hline 9 & $\begin{array}{l}\text { Smooth presentation } \\
\text { of brand/product }\end{array}$ & (4) & $\begin{array}{l}\text { Whether the presentation of product within the micro cinema being natural will } \\
\text { affect the number of viewers }\end{array}$ \\
\hline 8 & High exposure rate & (5) & $\begin{array}{l}\text { Whether the amount of exposure of the micro cinema affect the number of } \\
\text { viewers }\end{array}$ \\
\hline 6 & $\begin{array}{l}\text { Spread through } \\
\text { activity }\end{array}$ & (6) & $\begin{array}{l}\text { Whether the micro cinema is paired with some sort of activity to spread will } \\
\text { affect the number of viewers }\end{array}$ \\
\hline \multicolumn{2}{|l|}{3} & \multirow{4}{*}{ (7) } & \multirow{4}{*}{$\begin{array}{l}\text { Whether the story, plot as well as its content are important in determining the } \\
\text { number of viewers }\end{array}$} \\
\hline 36 & & & \\
\hline 23 & Plot & & \\
\hline 18 & Content & & \\
\hline 4 & \multirow{3}{*}{ Creativity } & \multirow{3}{*}{ (8) } & \multirow{3}{*}{ Whether the creativity level of the micro cinema affects the number of viewers } \\
\hline 5 & & & \\
\hline 25 & & & \\
\hline 26 & Interest & (9) & Whether the micro cinema being interesting can affect the number of viewers \\
\hline 7 & \multirow{2}{*}{ Popular idol or actor } & \multirow{2}{*}{ (10) } & \multirow{2}{*}{$\begin{array}{l}\text { Whether having a popular idol or an actor within the micro cinema can affect the } \\
\text { number of viewers }\end{array}$} \\
\hline 20 & & & \\
\hline 19 & Famous director & $(11)$ & Whether having a famous director can affect the number of viewers \\
\hline 10 & $\begin{array}{l}\text { Combined with public } \\
\text { service }\end{array}$ & $(12)$ & $\begin{array}{l}\text { Whether having commercial combined with public service can affect the number } \\
\text { of viewers }\end{array}$ \\
\hline 11 & Suspense & $(13)$ & $\begin{array}{l}\text { Whether having good suspense within the micro cinema can affect the number } \\
\text { of viewers }\end{array}$ \\
\hline 12 & \multirow{3}{*}{ Background music } & \multirow{3}{*}{$(14)$} & \multirow{3}{*}{$\begin{array}{l}\text { Whether having background music within the micro cinema can affect the } \\
\text { number of viewers }\end{array}$} \\
\hline 31 & & & \\
\hline 32 & & & \\
\hline 13 & \multirow{2}{*}{$\begin{array}{l}\text { Master the psychology } \\
\text { of audience }\end{array}$} & \multirow[t]{2}{*}{$(15)$} & \multirow{2}{*}{$\begin{array}{l}\text { Whether being able to affect the psychology of audience using the micro cinema } \\
\text { can affect the number of viewers }\end{array}$} \\
\hline 24 & & & \\
\hline 14 & $\begin{array}{l}\text { Integration method } \\
\text { between product and } \\
\text { story }\end{array}$ & $(16)$ & $\begin{array}{l}\text { Whether the integration method between the product and the story within the } \\
\text { micro cinema can affect the number of viewers }\end{array}$ \\
\hline 15 & \multirow{3}{*}{ Humor } & \multirow{3}{*}{$(17)$} & \multirow{3}{*}{$\begin{array}{l}\text { Whether having humor within the micro cinema can affect the number of } \\
\text { viewers }\end{array}$} \\
\hline 30 & & & \\
\hline 33 & & & \\
\hline 16 & Duration & $(18)$ & Whether the duration of the micro cinema can affect the number of viewers \\
\hline
\end{tabular}

Table 2.

Factors that affect micro cinema advertisement and questionnaire options 


\begin{tabular}{llll}
\hline $\begin{array}{c}\text { Original } \\
\text { code }\end{array}$ & $\begin{array}{c}\text { Factors affecting } \\
\text { micro cinema } \\
\text { advertisement }\end{array}$ & $\begin{array}{l}\text { New } \\
\text { code }\end{array}$ & Questionnaire options \\
\hline 17 & Fine screen & (19) & $\begin{array}{l}\text { Whether having fine screen for the micro cinema can affect the number of } \\
\text { viewers }\end{array}$ \\
\hline 28 & Celebrity endorsement & (20) & Whether having a celebrity endorsement can affect the number of viewers \\
\hline 29 & Similar background & (21) & $\begin{array}{l}\text { Whether having similar background in the micro cinema with local people can } \\
\text { affect the number of viewers }\end{array}$ \\
\hline
\end{tabular}

Source: Authors' own study.

\subsection{Questionnaire design and distribution}

In order to conduct an in depth analysis of whether the factors affecting the success of micro cinema advertisement will vary depending on the group of users, the questionnaires created were spread into three main groups of people: Taiwanese students, a Taiwanese working group and a Mainland China working group. The main reasons for selecting these three groups are as follows: micro cinema development began in Mainland China and since Taiwan shares the same language, it is easy to compare between the working groups in Taiwan and in China. Additionally, Taiwanese student group was added to see whether this focus group will differ from the working group.

The questionnaires were divided into three parts. The first part is the introduction to the report which includes the purpose of the survey, followed by questioning whether the participants have watched micro cinema advertisement before since people who have not watched one are not qualified to act as survey participants. The second part is the content. 21 questions were made from a new column in Table 2. A Likert scale of assessment was used to assess them. The third part is the survey on the participants' personal data such as age, gender, occupation, etc.

The questionnaires are focused on people who have previously watched micro cinema in the period from August 10, 2013 to August 20, 2013, and a total of 821 questionnaires were distributed. Out of the 821, 600 and 211 valid and invalid questionnaires were received, respectively. 200 valid questionnaires were returned from each group of the three.

\subsection{Use of GRA to determine the factors important to micro cinema advertisement}

After utilizing the GRA calculation formula on the collected questionnaires, the grey relational degrees for each question for each group were obtained. The obtained value for each question in each group can be seen in Table 3 .

\begin{tabular}{|c|c|c|c|c|}
\hline \multirow{2}{*}{\multicolumn{2}{|c|}{$\begin{array}{l}\text { Factors which influence the micro } \\
\text { cinema advertisement }\end{array}$}} & \multicolumn{3}{|c|}{ Grey relational value of each group } \\
\hline & & $\begin{array}{l}\text { Students } \\
\text { (Taiwan) }\end{array}$ & $\begin{array}{l}\text { Working group } \\
\text { (Taiwan) }\end{array}$ & $\begin{array}{l}\text { Working group } \\
\text { (China) }\end{array}$ \\
\hline (1) & $\begin{array}{l}\text { Whether or not the micro cinema advertisement focuses } \\
\text { on emotion is an important factor in attracting users }\end{array}$ & 0.73 & 0.73 & 0.71 \\
\hline & $\begin{array}{l}\text { Whether the level of commercialization is one of the } \\
\text { factors which affect the number of users }\end{array}$ & 0.44 & 0.47 & 0.40 \\
\hline
\end{tabular}

Determining the Key

Factors for the Advertisement on Micro Cinema Using Grey Relational Analysis and Dramaturgy Model 
Pobrane z czasopisma International Journal of Synergy and Research http://ijsr.journals.umcs.pl

Data: 26/04/2023 13:20:57

40

IJSR

7
Table 3.

The grey relational degree value for each factor in each group
Factors which influence the micro cinema advertisement

(3) Whether the placement of product in the movie being overly obvious affects the number of viewers

(4) Whether the presentation of product within the micro cinema, being natural, will affect the number of viewers

(5) Whether the amount of exposure of the micro cinema affects the number of viewers

(6) Whether the micro cinema is paired with some sort of activity to spread will affect the number of viewers

(7) Whether the story, plot as well as its content are important in determining the interest and number of viewers

(8) Whether the creativity level of the micro cinema affects the number of viewers

0.83

0.78

0.84

(9) Whether the micro cinema, being interesting, can affect the number of viewers

(10) Whether having a popular idol or an actor within the micro cinema can affect the number of viewers

(11) Whether having a famous director can affect the number of viewers

0.78

Students Working group Working group

(Taiwan)

(Taiwan)

(China)

0.45

0.49

0.41

0.68

0.71

0.65

0.64

0.64

0.52

0.61

0.61

0.52

0.82

0.76

0.83

Whether having a commercial combined with public service can affect the number of viewers

(13) Whether having good suspense within the micro cinema can affect the number of viewers Whether having background music within the micro cinema can affect the number of viewers

0.76

0.63

0.64

0.66

0.55

0.59

0.59

0.62

0.62

0.64

0.62

Whether being able to affect the psychology of audience using the micro cinema can affect the number

0.75

0.72

0.68 of viewers

(16) Whether the integration method between the product and the story within the micro cinema can affect the

0.71 0.67

0.65 number of viewers

(17) Whether having humor within the micro cinema can affect the number of viewers

0.77

0.73

0.72

(18) Whether the duration of the micro cinema can affect the number of viewers

0.74

0.71

0.74

(19) Whether having fine screen for the micro cinema can affect the number of viewers

0.71

0.68

0.75

(20) Whether having a celebrity endorsement can affect the number of viewers

0.59

0.61

0.61

(21) Whether having similar background in the micro cinema with local people can affect the number of viewers

0.75

0.73 0.66

Source: Authors' own study. 
Daniel (1961) pointed out that there are 3 to 6 main factors affecting the success of an enterprise. However, if the implementation of these factors as compared to a rival company is not sufficiently outstanding, then the success of the business will be difficult. Thus, this study was focused on various groups and the questionnaires' grey values are plotted on number line (see Figure 1). According to the graph, 3 to 6 factors which have the highest value are the main factors which affect the micro cinema advertisement. The questionnaire's questions and its corresponding value can be seen in Table 4.

Taiwan students

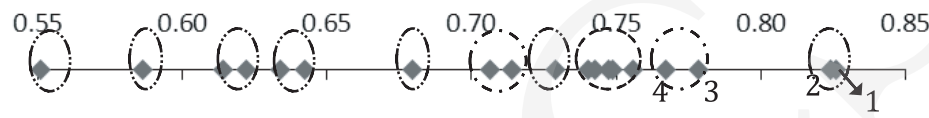

Working group

(Taiwan)

0.55
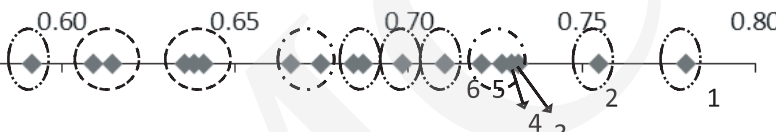

Working group

(China)
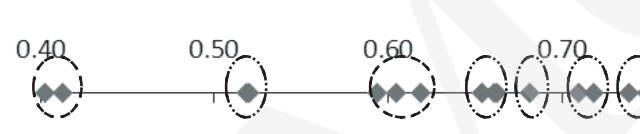
30.80

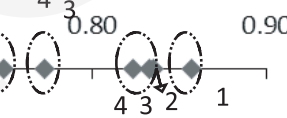

Source: Authors' own study.

\begin{tabular}{|c|c|c|c|c|}
\hline Group & Code $^{1}$ & Questionnaire option ${ }^{2}$ & $\begin{array}{l}\text { Important } \\
\text { factor }^{3}\end{array}$ & $\begin{array}{c}\text { Grey } \\
\text { relational } \\
\text { value }\end{array}$ \\
\hline \multirow{4}{*}{$\begin{array}{l}\text { Students } \\
\text { (Taiwan) }\end{array}$} & A1 & $\begin{array}{l}\text { Creative method in making micro cinema advertisement attracted } \\
\text { my interest }\end{array}$ & Creativity & 0.83 \\
\hline & $A 2$ & $\begin{array}{l}\text { Theme and storyline of micro cinema advertisement attracted my } \\
\text { interest }\end{array}$ & Good storyline & 0.82 \\
\hline & A3 & Interesting micro cinema advertisement attracted my interest ${ }^{* *}$ & Interesting & 0.78 \\
\hline & A4 & Humorous micro cinema advertisement attracted my interest ${ }^{* *}$ & Humor & 0.77 \\
\hline \multirow{6}{*}{$\begin{array}{l}\text { Working } \\
\text { group } \\
\text { (Taiwan) }\end{array}$} & B1 & $\begin{array}{l}\text { Creative method in making micro cinema advertisement attracted } \\
\text { my interest }{ }^{* * *}\end{array}$ & Creativity & 0.78 \\
\hline & B2 & $\begin{array}{l}\text { Theme and storyline of micro cinema advertisement attracted my } \\
\text { interest }\end{array}$ & Good storyline & 0.76 \\
\hline & B3 & Humorous micro cinema advertisement attracted my interest ${ }^{* *}$ & Humor & 0.73 \\
\hline & B4 & Emotional micro cinema advertisement attracted my interest & Emotion & 0.73 \\
\hline & B5 & $\begin{array}{l}\text { Micro cinema advertisement with similar background and culture } \\
\text { attracted my interest }\end{array}$ & $\begin{array}{l}\text { Similar } \\
\text { background }\end{array}$ & 0.73 \\
\hline & B6 & $\begin{array}{l}\text { Micro cinema advertisement with good understanding of the } \\
\text { audience's heart attracted my interest }\end{array}$ & $\begin{array}{l}\text { Good } \\
\text { understanding } \\
\text { of the audience's } \\
\text { heart }\end{array}$ & 0.72 \\
\hline
\end{tabular}

Table 4.

The grey relational value of each question for each group

Advertisement on Micro Cinema Using Grey Relational Analysis and Dramaturgy Model

Figure 1.

The linear grey relational degree line of factors affecting micro cinema advertisement for each group 


\section{IJSR}

7

Table 4.

The grey relational value of each question for each group

\begin{tabular}{lcllc}
\hline & C1 & Interesting micro cinema advertisement attracted my interest & Interesting & 0.86 \\
\cline { 2 - 5 } $\begin{array}{l}\text { Working } \\
\text { group }\end{array}$ & $\begin{array}{l}\text { Creative method in making micro cinema advertisement attracted } \\
\text { my interest }\end{array}$ & Creativity & 0.84 \\
\cline { 2 - 5 } & China) & $\begin{array}{l}\text { Theme and storyline of micro cinema advertisement attracted my } \\
\text { interest }\end{array}$ & Good storyline & 0.83 \\
\cline { 2 - 5 } & C4 $\begin{array}{l}\text { Micro cinema advertisement with good combination and } \\
\text { presentation of background music attracted my interest }\end{array}$ & $\begin{array}{l}\text { Background } \\
\text { music }\end{array}$ & 0.82 \\
\hline
\end{tabular}

Notes:

${ }^{1}$ sequence was done according to the grey relational value from large to small as well as different groups;

${ }^{2}$ column, the sign at the end of the option; ${ }^{* * *}$ - represented the fact that all three groups believed that it is an important factor; ${ }^{* *}$ - represented the fact that two of the three groups believed that it is an important factor.

${ }^{3}$ it is the main concept of the option which can be seen in Table 2.

Source: Authors' own study.

From Table 4, it can be seen that the Taiwanese student group focused on 4 factors (creativity, good storyline, interesting, and humor); Taiwanese working group focused on 6 factors (creativity, good storyline, humor, emotion, background information and capability to capture the heart of audience); Mainland China working group focused on 4 factors (interesting, creativity, good storyline and music background). Among the factors, creativity and good storyline were regarded to be the important factors affecting micro cinema advertisement by all three groups; Being interesting was one of the important factors affecting micro cinema advertisement by Taiwanese students and Mainland China working groups; Being humorous was one of the important factors affecting micro cinema advertisement by Taiwanese student and Taiwanese working groups.

\subsection{Use the dramaturgy model to discuss the important factors affecting micro cinema advertisement}

The four facets of dramaturgy model - location, actor, audience, and performance are very important to micro cinema advertisement. This study extracted the important factors in Grove and Fisk and Grove et al. (1989; 1992) (14 variables) and applied it to the dramaturgy model as shown in Table 5. The conversion was based on whether or not it can be used in micro cinema advertisement. In Table 5, the third column ("Variables on micro cinema advertisement") includes the modified variables that can be used in micro cinema advertisement. As an example, one of the original variables "Location's hygiene" is not applicable to micro cinema advertisement and, thus, it is not modified. Variables that can or cannot be modified to be used in micro cinema advertisement can be seen in Table 5, which altogether form 8 usable variables. 
Pobrane z czasopisma International Journal of Synergy and Research http://ijsr.journals.umcs.pl

Data: 26/04/2023 13:20:57

\begin{tabular}{|c|c|c|}
\hline Facets & Original dramaturgy model variables & $\begin{array}{c}\text { Variables on micro cinema } \\
\text { advertisement }\end{array}$ \\
\hline \multirow{3}{*}{$\begin{array}{l}\text { Location - acts as the scenery in } \\
\text { micro cinema advertisement }\end{array}$} & Location's scenery & $\begin{array}{l}\text { Tools and scenery in micro cinema } \\
\text { advertisement }\end{array}$ \\
\hline & Location's space management & \\
\hline & Location's hygiene & \\
\hline \multirow{4}{*}{$\begin{array}{l}\text { Actors - people who perform in } \\
\text { the micro cinema advertisement }\end{array}$} & Actors' costume and make-up & Actors' costume and make-up \\
\hline & Actors' emotion and behavior & Actors' attitude and behavior \\
\hline & Actors'skills & \\
\hline & Actors' expectation towards the audience & \\
\hline \multirow{3}{*}{$\begin{array}{l}\text { Audience - people who watch } \\
\text { micro cinema advertisement }\end{array}$} & $\begin{array}{l}\text { Attitude of audience when cooperating in the } \\
\text { performance }\end{array}$ & $\begin{array}{l}\text { Attitude of audience when watching } \\
\text { micro cinema advertisement }\end{array}$ \\
\hline & $\begin{array}{l}\text { Behavior of audience when cooperating in the } \\
\text { performance }\end{array}$ & $\begin{array}{l}\text { Behavior of audience when watching } \\
\text { micro cinema advertisement }\end{array}$ \\
\hline & Interaction among the audience & Interaction among the audience \\
\hline \multirow{4}{*}{$\begin{array}{l}\text { Performance - design of the } \\
\text { storyline for micro cinema } \\
\text { advertisement }\end{array}$} & Flow of performance and design & Design of storyline \\
\hline & Execution of performance & \\
\hline & Combination of service performance & \\
\hline & Quality of product & Quality of micro cinema advertisement \\
\hline
\end{tabular}

Remark: Boxes that are crossed are variables that cannot be used in micro cinema advertisement.

Source: Authors' own study.

Afterwards, the 8 modified variables became the standard for discussing the important factors affecting micro cinema advertisement. In Table 4, the extracted factors for each group are sorted according to the 8 modified variables. However, not all of the important factors are suitable to be grouped into the 8 variables. Some of the factors may be suited to multiple variables which are tabulated into Table 6 .

\begin{tabular}{|c|c|c|c|}
\hline Group & Code $^{1}$ & Important factor & Variables $^{2}$ \\
\hline \multirow{4}{*}{$\begin{array}{l}\text { Students } \\
\text { (Taiwan) }\end{array}$} & A1 & Creativity & $\begin{array}{l}\text { 1. Tools and scenery in micro cinema advertisement } \\
\text { 2. Actors' costume and make-up } \\
\text { 3. Behavior of audience when watching micro cinema advertisement } \\
\text { 4. Design of storyline }\end{array}$ \\
\hline & $A 2$ & Good storyline & 1. Behavior of audience when watching micro cinema advertisement \\
\hline & A3 & Interesting & $\begin{array}{l}\text { 1. Tools and scenery in micro cinema } \\
\text { 2. Actors' costume and make-up } \\
\text { 3. Behavior of audience when watching micro cinema advertisement } \\
\text { 4. Interaction among the audience } \\
\text { 5. Design of storyline }\end{array}$ \\
\hline & A4 & Humorous & $\begin{array}{l}\text { 1. Tools and scenery in micro cinema } \\
\text { 2. Attitude of audience when watching micro cinema advertisement } \\
\text { 3. Design of storyline }\end{array}$ \\
\hline
\end{tabular}

Determining the Key

Factors for the Advertisement on Micro Cinema Using Grey Relational Analysis and Dramaturgy Model

Table 5.

Original variables in the dramaturgy model and its modified version

to suit micro cinema advertisement
Table 6.

Important factor of each group in accordance to the modified variables 
Pobrane z czasopisma International Journal of Synergy and Research http://ijsr.journals.umcs.pl Data: 26/04/2023 13:20:57

44

\section{IJSR}

7

Table 6.

Important factor of each group in accordance to the modified variables

\begin{tabular}{|c|c|c|c|}
\hline Group & Code $^{1}$ & Important factor & Variables $^{2}$ \\
\hline \multirow{15}{*}{$\begin{array}{l}\text { Working } \\
\text { group } \\
\text { (Taiwan) }\end{array}$} & \multirow{4}{*}{ B1 } & \multirow{4}{*}{ Creativity } & 1. Tools and scenery in micro cinema \\
\hline & & & 2. Actors' costume and make-up \\
\hline & & & 3. Behavior of audience when watching micro cinema advertisement \\
\hline & & & 4. Design of storyline \\
\hline & B2 & Good storyline & 1. Behavior of audience when watching micro cinema advertisement \\
\hline & \multirow{3}{*}{ B3 } & \multirow{3}{*}{ Humorous } & 1. Tools and scenery in micro cinema \\
\hline & & & 2. Behavior of audience when watching micro cinema advertisement \\
\hline & & & 3. Design of storyline \\
\hline & \multirow{2}{*}{ B4 } & \multirow{2}{*}{ Emotional } & 1. Actors' emotion and behavior \\
\hline & & & 2. Design of storyline \\
\hline & \multirow{4}{*}{ B5 } & \multirow{4}{*}{ Similar background } & 1. Tools and scenery in micro cinema \\
\hline & & & 2. Actors' costume and make-up \\
\hline & & & 3. Actors' emotion and behavior \\
\hline & & & 4. Design of storyline \\
\hline & B6 & $\begin{array}{l}\text { Good } \\
\text { understanding of } \\
\text { the audience's heart }\end{array}$ & $\begin{array}{l}\text { 1. Quality of micro cinema advertisement } \\
\text { 2. Design of storyline }\end{array}$ \\
\hline \multirow{11}{*}{$\begin{array}{l}\text { Working } \\
\text { group } \\
\text { (China) }\end{array}$} & \multirow{5}{*}{ C1 } & \multirow{5}{*}{ Interesting } & 1. Tools and scenery in micro cinema \\
\hline & & & 2. Actors' costume and make-up \\
\hline & & & 3. Behavior of audience when watching micro cinema advertisement \\
\hline & & & 4. Interaction among the audience \\
\hline & & & 5. Design of storyline \\
\hline & \multirow{4}{*}{$\mathrm{C} 2$} & \multirow{4}{*}{ Creativity } & 1. Tools and scenery in micro cinema \\
\hline & & & 2. Actors' costume and make-up \\
\hline & & & 3. Behavior of audience when watching micro cinema advertisement \\
\hline & & & 4. Design of storyline \\
\hline & C3 & Good storyline & $\begin{array}{l}\text { 1. Behavior of audience when watching micro cinema advertisement } \\
\text { 2. Design of storyline }\end{array}$ \\
\hline & C4 & Background music & 1. Quality of micro cinema advertisement \\
\hline
\end{tabular}

Notes:

1 the column is according to the sequence that can be seen in Table 4 .

2 the column comes from the modified variables which can be seen in Table 5 .

Source: Authors' own study.

The results in Table 6, when used in the future by the micro cinema industry, can be used as indicators. For example, in the Taiwanese student group, creativity is an important factor. In order to know whether the created micro cinema fulfills this criteria, one can check from "tools and scenery in micro cinema advertisement", "actors", "costume and make-up", "behavior of audience when watching micro cinema advertisement", and "design of storyline", for these four indicators. Further comparison between the factors affecting the Taiwanese working group and Mainland Chinese working group will also show their corresponding results. 


\section{Conclusions}

Compiled results of this study can be seen in the conclusions below:

1. After referencing to the past literature on micro cinema advertisement, the summarized factors were then developed into questionnaires. GRA were used to extract the important factors to micro cinema advertisement according to the Taiwanese student group, Taiwanese working group and Mainland China working group.

2. For important factors to micro cinema advertisement, the Taiwanese student group showed 4 factors: creativity, good storyline, being interesting, and humor; Taiwanese working group indicated 6 factors: creativity, good storyline, humor, emotional, similar background and being able to grasp the audience's heart; and Mainland China working group emphasized 4 factors: being interesting, creativity, good storyline, and music background. All three groups believed that creativity and good storyline are important, whereas the Taiwanese student group and Mainland China working group believed that being interesting is important and the Taiwanese student group and Taiwanese working group believed that humor is important.

3. In the service sector, the dramaturgy model has 14 variables which were then converted to suit micro cinema advertisement. There are altogether 8 modified variables which were then used as indicators to test the level of impact on each factors extracted from the three groups on micro cinema advertisement. These indicators can then be used as a guide for people in the micro cinema industry.

\section{References}

Baldwin, H. (1997), How to Create Effective TV Commercials, Natl Textbook Co Trade.

Bayles, E.M. (2002), Designing online banner advertisements: Should we animate? Conference on Human Factors in Computing Systems, pp. 363-366. Minneapolis, Minnesota, USA.

Chen, A. (2012), “Are you making micro-film, or pseudo-movies?", Yahoo Digital Marketing Column, available at: http://tw.marketing.campaign.yahoo.net/emarketing/contentF4.php?m ain $=\mathrm{A} 01 \&$ sub $=\mathrm{B} 02 \&$ tri $=\&$ literary $=482$ (accessed: 15 October 2012).

Chen, C. (2013), "Constructing the perspective of micro-film advertising and marketing in emotional appeal", Modern Business, vol. 5, pp. 55-56.

Chen, H. (2002), "Summary of Goffman's dramaturgy model theoretical concepts", Network Communication Sociology Journals, vol. 20, available at: http://mail.nhu.edu.tw/ society/ e-j/20/20-14.htm

Chen, X., Huang, X., and Tan, X. (2010), "Polar grey relational analysis on sexual satisfaction and hemoglobin in essential hypertensive patients", Journal of Grey System, vol. 22, no. 1, pp. 89-96.

Chen, J.H., Chang, T.T., and Ho, C.R. (2014), "Grey relational analysis and neural network forecasting of REIT returns", Quantitative Finance, vol. 14, no. 11, pp. 2033-2044.

Chiu, W.Y., Tzeng, G.H., and Li, H.L. (2014), "Developing e-store marketing strategies to satisfy customers' needs using a new hybrid gray relational model", International Journal of Information Technology \& Decision Making, vol. 13, no. 2, pp. 231-261.

Cline, T.W., and Kellaris, J.J. (2007), "The influence of humor strength and humor. Message relatedness on ad memorability", Journal of Advertising, vol. 36, no. 1, pp. 55-67.

Cline, T.W., Altsech, M.B., and Kellaris, J.J. (2003). "When does humor enhance or inhibit ad responses?: The moderating role of the need for humor", Journal of Advertising, vol. 32, pp. $31-46$.

Daniel, R.D. (1961), "Management information crisis", Harvard Business Review, vol. 39, pp. 111-121.

\section{Determining the Key \\ Factors for the Advertisement on Micro Cinema Using Grey Relational Analysis and Dramaturgy \\ Model}


IJSR 7

Deng, J. (1989), "Introduction to grey system”, The Journal of Grey System, vol. 1, no. 1, pp. 1-24. Deng, J. (2000), Grey System Theory and Applications, Gaoli books, New Taipei City.

Erdogan, B.Z., Baker, M.J., and Tagg, S. (2001), "Selecting celebrity endorsers: The practitioner's perspective", Journal of Advertising Research, vol. 41, pp. 39-48.

Goffman, E. (1959), The Presentation of Self in Everyday Life, Doubleday, Anchor Books, New York.

Grove, S.J. and Fisk, R.P. (1989), "Impression Management in Services Marketing: A Dramaturgical Perspective. Impression Management in the Organization", in: R.A. Giacalone, P. Rosenfeld (eds.), Impression Management in the Organization, Erlbaum, Hillsdale, NJ., pp. 427-483.

Grove, S.J., Fisk, R.P., and Bitner, M.J. (1992), "Dramatizing the service experience: A managerial approach", Advances in Services Marketing and Management, vol. 1, pp. 91-121.

Ho, C.W. (2013), "A study of video production applied in the strategy of marketing communication - taking real estate advertising images as an example", Fu Hsing Kang Academic Journal, vol. 103, pp. 83-115.

Hsu, L.-C., Ou, S.L., and Ou, Y.C. (2015), “A comprehensive performance evaluation and ranking methodology under a sustainable development perspective", Journal of Business Economics and Management, vol. 16, no. 1, pp. 74-92.

Hu, J. (2014), "Micro-film marketing - telling a good story about your brand", Journal of Southwest Jiaotong University, vol. 2, pp. 52-56.

Hu, G.S., and Chen, C.M. (2013), "A preliminary study of the application of micro-film in military marketing communication”, Fu Hsing Kang Academic Journal, vol. 103, pp. 1-23.

Huang, J. and Liao, R. (2012), "Use of Data Envelopment and Gray Relational Analysis to Measure the Performance of the Electronic Tags", Quality Technology, vol. 19, no. 2, pp. 137-156.

Kang, C. (2012), "Discussion on the development of micro-film advertisement", Press, vol. 15, pp. $45-49$.

Kuo, M.H. (2016), "Analysis of practice and study on micro-film marketing for China's Library", New Century Library, vol. 06, pp. 33-36.

Lee, S. (2012), "Case analysis of micro-film advertisement model using micro-film for automobile brand", Today's Media, vol. 9.

Liao, G., Huang, B., Yang, J., Jiang, F., Ouyang, Q., and Chen, N. (2014), "Does micro-film story advertisement is better than TV advertisement? - comparison done using their effect on target products", Integrated Textile Research Journal, vol. 24, no. 3, pp. 44-55.

Lin, Y. (2013), "Alluring smile - discussing the degree of grasp on the business value of micro-film advertising", Movie Review, vol. 6, pp. 73-74.

Liou, D. (2012). "Public micro film: Transformation of »Creative Officer Advertising« - discussed from »Love Legend «", New Film, vol. 2, pp. 6-8.

Liou, S. (2013), "Analysis and Dissemination of Results of Micro-film Related Factors", Xihua University Report, vol. 32, no. 1, pp. 27-31.

List of popular micro-film on YouTube, available at: http://www.youtube.com/playlist?list=PLYrt OyPOOjPLyFZ7OatHHkSjV1S_PvOcO (accessed: 5 December 2012).

Liu, M.H., and Tsai, D.R. (2012), "The advantages and influence of micro cinema marketing", Brain Communications, available at: https://www.brain.com.tw/news/articlecontent?ID=17973 (accessed: 20 January 2018).

McCarty, J.A. (2004), "Product placement: The nature of the practice and potential avenues of inquiry", in: L.J. Shrum (ed.), The Psychology of Entertainment Media, Taylor and Francis Group, NY, pp. 45-61.

Orth, U.R., and Oppenheim, P.P. (2005), Measuring message framing effects across Europe, Journal of Targeting, Measurement and Analysis for Marketing, vol. 13, no. 4, pp. 313-326. 
Otto, J.E., and Ritchie, J.R.B. (1996), “The service experience in tourism”, Tourism Management, vol. 17 , no. 3 , pp. $165-174$.

Pai, J., and Lu, H. (2012), “Marketing of micro-film advertisement”, News Junkies, vol. 10, pp. 69-71.

$\mathrm{Qu}, \mathrm{W}$. (2013), "Reflecting the position and psychological status of micro film in the future market of film and television", Life of Music, vol. 4, pp. 85-87.

Radstone, S. (2010), "Cinema and Memory”, in: S. Radstone, B. Schwarz (eds.), Memory. Histories, Theories, Debates, Fordham University Press, New York, pp. 325-343.

Wikipedia (2017), Microcinema, available at: https://en.wikipedia.org/wiki/Microcinema (accessed: 17 January 2017).

Wu, P.H. (2017), "Strategies of micro film marketing by brand culture communication in the era of new media", Heihe Academic Journal, vol. 10, pp. 50-51.

Zhang, E. (2011), "Determining factors to explore the relevance between volleyball game scores and achievements using grey relational analysis", Physical Education, vol. 44, no. 2, pp. 55-64.

Zhang, H. (2012), "Business opportunities in storytelling - micro-film marketing - appeal to your heart", Trade Magazines, vol. 252, pp. 34-37.

Zhu, J. (2011), Research on the new media age of micro-film advertising and marketing, Master's thesis, Anhui University, Anhui Province, China.
Determining the Key

Factors for the Advertisement on Micro Cinema Using Grey Relational Analysis and Dramaturgy

Model 